\title{
G-Protein Coupled Receptor 15
}

National Cancer Institute

\section{Source}

National Cancer Institute. G-Protein Coupled Receptor 15. NCI Thesaurus. Code

C140247.

G-protein coupled receptor 15 (360 aa, $\sim 41 \mathrm{kDa}$ ) is encoded by the human GPR15 gene.

This protein plays a role in the modulation of $\mathrm{T}$-cell migration. 